$1-2008$

\title{
The Scope of Criminal Law and Criminal Sanctions: An Economic View and Policy Implications
}

Roger Bowles

Michael Faure

Nuno Garoupa

ngaroup@gmu.edu

Follow this and additional works at: https://scholarship.law.tamu.edu/facscholar

Part of the Law Commons

\section{Recommended Citation}

Roger Bowles, Michael Faure \& Nuno Garoupa, The Scope of Criminal Law and Criminal Sanctions: An Economic View and Policy Implications, 35 J.L. \& Soc'y 389 (2008).

Available at: https://scholarship.law.tamu.edu/facscholar/548

This Article is brought to you for free and open access by Texas A\&M Law Scholarship. It has been accepted for inclusion in Faculty Scholarship by an authorized administrator of Texas A\&M Law Scholarship. For more information, please contact aretteen@law.tamu.edu. 


\title{
The Scope of Criminal Law and Criminal Sanctions: An Economic View and Policy Implications
}

\author{
Roger Bowles, ${ }^{*}$ Michael Faure, ${ }^{* *}$ and Nuno Garoupa***
}

This paper considers why some harm-generating activities are controlled by criminal law and criminal sanctions while others are subject to some other mechanism such as civil law, administrative law, regulation or the tax system. It looks at the question from the perspective of the law and economics approach. We seek to identify the comparative benefits of using the criminal law relative to other enforcement mechanisms and - more broadly - why certain specific behaviours are criminalized. The paper argues that an economic approach emphasizing the relative merits of alternative legal instruments for bringing about harm reduction can provide an explanation for a number of recent legal developments. It argues also that the willingness of legislators to combine the use of sanctions traditionally used in one area of the law with sanctions from other areas is more readily explicable in economic terms than in other terms.

* Centre for Criminal Justice Economics and Psychology, Wentworth College, University of York, York YO10 5DD, England

rab12@york.ac.uk

** Law School, Maastricht University, PO Box 616, 6200 MD Maastricht, The Netherlands

michael.faure@facburfdr.unimaas.nl

*** University of Illinois College of Law, 504 East Pennsylvania Avenue, Champaign, Illinois 61820, United States of America

ngaroupa@law.uiuc.edu

We are grateful to participants in the conference of the European Association of Law and Economics in Ljubljana (September 2005) and to J.J. Prescott for very useful comments. We are grateful also to Alon Harel and Iñigo Ortiz de Urbina and to four anonymous referees for detailed written comments on earlier versions of the paper and to participants in a seminar on legal theory at Maastricht University. Roger Bowles and Nuno Garoupa acknowledge financial support from the EC in respect of project 044422, 'Mainstreaming Methodology for Estimating the Costs of Crimes'. Nuno Garoupa acknowledges financial support from POCI/JUR/55752/2004, FCT. The usual disclaimers apply. 


\section{INTRODUCTION}

Why are certain acts or omissions subjected to the criminal law or to criminal sanctions while others that appear equally harmful are not? The purpose of this paper is to contrast a legal approach to this question with the approach used in economics and particularly in the 'law and economics' literature. We argue that the principal difference between the two perspectives is that the legal approach tends to focus on the characteristics of harm-creating activities whilst the economic approach tends to focus on the relative merits of criminal law as a means of controlling the volume of harm produced.

Few things are universally regarded as a crime. There are variations both through time ${ }^{1}$ and across space in what is criminalized. ${ }^{2}$ Criminal behaviour is a matter that is culturally and historically bound. Still the question arises why, if society is to control some kind of behaviour, this is best done through the criminal law. Decisions about the activities to be prevented or deterred are separable from the choice of legal instrument for control. Many legal devices, such as civil remedies or administrative actions, are alternatives to, or complements to, the criminal law. The benefits of using criminal law need to be compared with those of other control mechanisms. The choice of control mechanism is thus inextricably linked with the broader issue of whether a particular type of behaviour is criminalized.

Our analysis is largely positive and seeks to avoid normative statements concerning the use of the criminal law. We argue that the law and economics approach may be useful in predicting circumstances in which criminal law or criminal sanctions might emerge as a preferred instrument as well as why it is (or has been) used for controlling some activities but not others.

Some theories supporting use of criminal law in fact merely provide arguments in favour of using a public enforcement and sanctioning mechanism. There are mechanisms other than the criminal law that can fulfil this function. We therefore also address the question of the extent to which criteria for applying alternative mechanisms, such as regulation, may also be relevant for a theory of criminalization. We argue that there are two stages in the test for criminalization. The first stage (necessary but not sufficient) is that the activity should be harmful. The second stage is that the criminal law should be a more efficient means of controlling the activity than other means. ${ }^{3}$ We see criminal law as a system having the following features:

1 For instance in the Middle Ages it was common to hold trials of animals and until recently in Belgium (and still today in other countries, including some North American states) adultery was criminalized.

2 One could refer to criminalization of activities with an ethical overtone such as abortion and gambling, and also to differences in criminalization with respect to the use of alcohol and certain kinds of drugs.

3 These other means may be primarily other legal instruments but they may also be non-legal instruments such as social norms. We use the term 'efficient' to convey the 
(i) conditions for using the criminal law are ex ante defined in public legislation or in common law (there is a pre-commitment by the state against ex post facto criminal laws essentially to avoid abuse);

(ii) criminal law is governed by rules and not standards;

(iii) criminal law can be applied primarily on the request of a public agent (prosecutor or agency);

(iv) sanctions are imposed by impartial judges, and

(v) criminal sanctions may include non-monetary sanctions, particularly imprisonment. ${ }^{4}$

We believe that these features distinguish criminal law from other sanctioning systems like private law (where both enforcement and sanctioning is different) and from administrative law. The latter system usually also allows a prosecution by an administrative agency, but there is imposition of sanctions by administrative agencies (not necessarily an impartial judge) and the imposition of a prison sanction is usually excluded from administrative systems. Of course there are grey areas, for instance, where victims may seek the private prosecution of criminal offences, but these are precisely the sorts of areas of interest for our analysis.

Our paper is structured as follows. Section II provides a legal perspective on why particular acts are defined as crimes. Section III presents the economic approach to crime and discusses the economic reasons for criminalization. Section IV presents some examples of the application of the economic approach. Section V concludes.

\section{LEGAL PERSPECTIVE}

We review first the treatment in criminal law doctrine of the question why certain kinds of behaviour are made subject to the criminal law.

\section{What is a criminal act?}

A criminal act is one defined as such by the penal code or the statutes. It is an act prohibited, prosecuted, and punished by criminal law. Criminal law specifies the acts and omissions that are regarded as a criminal act. ${ }^{5}$ There is no simple, universal legal definition of a criminal act, but some notions are common. First, a criminal act does public harm, possibly on a substantial scale. In addition, there is a 'third-party interest' in the harm. The prospect of

idea that the cost of a control mechanism may play a role in the criminalization decision as well as its efficacy in preventing the harmful behaviour.

4 Other sanctions such as specific prohibitions may also be included here, for example, orders prohibiting individuals from engaging in activities such as driving or attending football matches.

5 See A. Ashworth, Principles of Criminal Law (2003) 96 ff. 
repetition causes citizens to incur costs in the form of feelings of apprehension and/or motivation to take precautions against becoming victims themselves of such harm in the future. In the case of torts, the nature of the harm is (at least in part) private whereas with crimes the harm is (at least in part) public. This difference is expressed by the fact that a tort action is brought by the victim (the plaintiff), whereas under criminal law a prosecution is normally brought by the state. ${ }^{6}$

A second important characteristic of legal definitions of a criminal act is that the agent should be aware of the possibility that their action will be, or might be, harmful. The mens rea ${ }^{7}$ requirement covers a spectrum of states of mind which includes, but is not limited to, instances where the agent sets out deliberately to harm a particular, identifiable individual. There are gradations in criminal intent which are relevant to guilt and punishment.

The person who commits a crime exposes him- or herself to the risk of punishment in some form: a fine in excess of compensation, imprisonment, and other forms of curtailing the criminal's freedom, or even execution in some jurisdictions. Whereas compensation in torts aims to restore the loss to the victim at the expense of the injurer, punishment in criminal law makes the injurer worse off without directly benefiting the victim. Due to the fact that compensation and punishment have different objectives, they can be independent and punishment may be imposed on top of compensation (notwithstanding the double jeopardy principle) ${ }^{8}$ Likewise, victims may be compensated by the state through taxpayer-funded schemes. ${ }^{9}$

We note also the distinction between the functions of the criminal law and the functions of sentencing. Without going into this in detail, ${ }^{10}$ it is clear that various objectives are pursued in sentencing including: deterrence, incapacitation (preventing re-offending at least for a time), rehabilitation, restoration, and reparation. The notion of 'retribution' in particular plays a central role in sentencing. This is not surprising in so far as the criminal law is conceived as a device to punish deviations from behaviour judged to be consistent with the smooth functioning of society. ${ }^{11}$ Criminalization, in this

6 See, for the English system, and more particularly the role of the Crown Prosecution Service, A. Ashworth and M. Redmayne, The Criminal Process (2005, 3rd edn.) 173 ff. Under the English system, however, prosecutions can be brought privately. Hence, not in all systems is prosecution the sole prerogative of the state.

7 See M.J. Allen, Textbook on Criminal Law (2003, 7th edn.) 49-95.

8 See, on the combination of compensation orders with other sanctions: A. Ashworth, Sentencing and Criminal Justice (2005, 4th edn.) 298-302. Likewise, confiscation orders may be used to complement sanctions such as imprisonment.

9 These schemes may be specifically related to criminal injuries or they may be generic schemes for compensating victims of injuries and accidents whatever their cause.

10 For the rationale of sentencing, see Ashworth, op. cit., n. 8, pp. 72-91.

11 Not all legal scholars of course restrict themselves to the retributive notion of criminalization. Restoration and reparation, for example, have most recently been brought up by the 'community justice' and 'restorative justice' movements, although they have not been much considered nor discussed by a majority of lawyers. For an 
setting, is intended to reflect social disapproval, not an attempt to ensure that an injured party is compensated. The right of the state to punish derives from the idea that the citizen has given up some rights of self-defence in exchange for protection by the state. ${ }^{12}$

Various prescriptions for criminalization are provided in the literature. First, the principles of individual autonomy and of welfare are advanced on the basis that individuals should be respected and treated as agents capable of choosing their acts and omissions. ${ }^{13}$ This is related to Hart's famous principle that an individual should not be held criminally liable unless he had the capacity and a fair opportunity to do otherwise. ${ }^{14} \mathrm{~A}$ consequence is that people's autonomy may not be infringed unless to protect or promote the autonomy of those people or others. This may lead to a minimalist approach towards the use of the criminal law. ${ }^{15}$

A second line of thought, also found in England but especially in German legal doctrine, is that criminalization should be reserved for the most serious attacks directed at the most important interests. ${ }^{16}$ This is in line with German legal dogmatics where the goal of the criminal law is to protect legal values or interests. ${ }^{17}$ This theory is also used by Von Hirsch and Jarenborg in order to identify the type of interests that ought to be protected by the criminal law. ${ }^{18}$ Increasing recognition of the importance of the protection of collective values and interests as well as of individual values and interests underpins the legal doctrine used to argue, for instance, that protection of environmental values should be extended via application of the criminal law. ${ }^{19}$ The task of assessing the seriousness of offences is, however, considered quite complex and problematic ${ }^{20}$ and therefore this approach may not necessarily explain why certain interests are to be protected by the criminal law.

argument that they are wrong in neglecting them, see $\mathrm{M}$. Tonry, 'Obsolescence and Immanence in Criminal Law Theory' (2005) 105 Columbia Law Rev. 1233-75.

12 N. MacCormick and D. Garland, 'Sovereign States and Vengeful Victims' in Fundamentals of Sentencing Theories, eds. A. Ashworth and M. Wasik (1998) 11-30.

13 Compare R. Dworkin, Taking Rights Seriously (1977) 180.

14 H.L.A. Hart, Punishment and Responsibility (1968).

15 Ashworth, op. cit., n. 5, pp. 28-30.

16 id., p. 35. This is in line with the argument that the criminal law should be used only as a last resort, even though Husak recently argued that the application of this last resort principle is unlikely to bring about sweeping changes in criminalization; see D. Husak, 'The Criminal Law as Last Resort' (2004) 24 Oxford J. of Legal Studies, 207-35.

17 In German terminology they are referred to as 'Rechtsgüter'. See the dissertation of K. Tiedemann, Tatbestandsfunktionen im Nebenstrafrecht (1969). For a more recent account, see R. Hefendehl, A. von Hirsch, and W. Wohlers. Die Rechtsgutstheorie (2004).

18 See A. von Hirsch and N. Jarenborg, 'Guauging Criminal Harms: a Living Standard Analysis' (1991) 11 Oxford J. of Legal Studies, $1 \mathrm{ff}$.

19 See, for instance, G. Heine and V. Meinberg, Empfehlen sich Änderungen im strafrechtlichen Umweltschutz, insbesondere in Verbindung mit dem Verwaltungsrecht? Gutachten D für dem 57. Juristentag (1988).

20 Ashworth, op. cit., n. 5, p. 41. 
A third approach relies on the harm principle. Criminalization may be necessary to prevent hurt or offence to citizens. ${ }^{21}$ Related to this harm principle is also the so-called minimalist approach which argues that criminalization should be reserved for the most serious invasions of interests and for when other forms of social control (civil liability, administrative regulation) may not suffice. ${ }^{22}$

This minimalist approach can also be found in continental legal doctrine where it has often been argued that the criminal law should, at the practical level, only be a means of last resort (a so-called ultima ratio). These scholars point to some inherent weaknesses in the criminal law, for instance, lack of capacity and expertise, and argue that the criminal law should only be used when other social control mechanisms fail. ${ }^{23}$ However, it is also recognized that sometimes criminalization may occur purely for symbolic reasons, even though this may not directly correspond with the harm principle. ${ }^{24}$ Moreover, reliance on the harm principle can not only be found in criminal law, but also, for example, in tort law. Hence, this harm principle cannot be used to distinguish criminal law from other legal instruments like tort.

A fourth, and traditionally important, argument in favour of criminalization is that criminal behaviour is immoral. Devlin defended in The Enforcement of Morals the proposition that the primary function of the criminal law was to maintain public morality. ${ }^{25}$ This led to intense debate in legal doctrine and even before the House of Lords. ${ }^{26}$ However, the view that it is the function of the criminal law to enforce morality is in decline. Not all rules of social morality are subject to enforcement by the criminal law (lying, adultery) and some behaviour may formally constitute an offence (speeding), but is not necessarily considered as immoral.

We conclude that the legal approach does not seem to be able (nor aim) to provide a satisfactory and complete answer as to why certain acts are criminalized and others not. Changing beliefs and attitudes about the rights and responsibilities of citizens find expression in changes in both legislation and judicial interpretation. Criminalization does not reflect any solid, unchanging body of doctrine: it is a response to what society deems to be acceptable and does not itself provide an explanation for these variations. ${ }^{27}$

The principal weakness of this position from an economic perspective is that it makes it difficult to predict how law will change. It is usually possible

21 See J. Feinberg, Harm to Others (1984).

22 Ashworth, op. cit., n. 5, pp. 33-7.

23 This can be found in the works of Dutch criminal legal scholars: L. Hulsman, Handhaving van Recht (1965); L. Hulsman, Afscheid van het Strafrecht. Een Pleidooi voor Zelfregulering (1986); Th. de Roos, Strafbaarstelling van Economische Delikten (1987), and others.

24 Ashworth, op. cit., n. 5, p. 36.

25 P. Devlin, The Enforcement of Morals (1965).

26 Ashworth, op. cit., n. 5, pp. 42-6; Allen, op. cit., n. 7, pp. 9-11.

27 Allen, id., p. 9. 
to look back and to produce explanations with the benefit of hindsight, but this avoids the challenge of prediction. But it is clearly an improvement on the notion that a crime is determined simply by what the criminal law says is a crime ${ }^{28}$ Of course economics is far from being the only social science offering an alternative view of the purpose of criminal law and criminal sanctions. Pressure of space precludes a comparison with perspectives from other disciplines. ${ }^{29}$

\section{ECONOMIC ARGUMENTS}

Economics treats criminal law as one of the mechanisms for controlling potentially harmful activities. Criminal law competes with alternatives such as civil law, administrative law, private cooperation, and excise taxes as a means of helping prevent those activities, and only those activities, which impose social costs that exceed their social benefits. ${ }^{30}$ The basic criterion is that, given the structure of the costs and benefits, criminal law is used if it enables society to get closer to a socially optimal level of harmful activity. The appropriate domain for the use of criminal law is thus determined pragmatically by the costs and benefits of using criminal law tools relative to those of using non-criminal instruments.

Much of the economic literature relies on conjectures about the effect on potentially criminal behaviour of institutions such as criminal law. It asks: do potential delinquents or injurers change their behaviour in response to different legal policy alternatives? But the deterrent capacity of criminal law is not the object of attention in this paper. ${ }^{31}$ A more relevant strand of the

28 See S. Jones, Criminology (2001, 2nd edn.) 30-3.

29 There is a vast literature about criminalization constructed in terms of the contest between political, social, and economic forces that is beyond the scope of the present article.

30 See S. Shavell, 'The Optimal Structure of Law Enforcement' (1993) $36 \mathrm{~J}$. of Law and Economics 255-87, for a general discussion.

31 That is the objective of the literature on optimal law enforcement. Since the seminal paper by Becker, it has focused on the balance between probability and severity of punishment as means of achieving efficient law enforcement. The main contribution of this literature is to provide a theory of criminal behaviour and how criminals react to incentives. See G. Becker, 'Crime and Punishment: An Economic Approach' (1968) $76 \mathrm{~J}$. of Political Economy 169-217. Recent updated surveys include N. Garoupa, 'The Theory of Optimal Law Enforcement' (1997) $11 \mathrm{~J}$. of Economic Surveys 267-96; A.M. Polinsky and S. Shavell, 'The Economic Theory of Public Enforcement of Law' (2000) 38 J. of Economic Literature 45-76; and A.M. Polinsky and S. Shavell, 'Public Enforcement of Law including Criminal Law' in Handbook of Law and Economics, eds. A.M. Polinsky and S. Shavell (2007) 403-54. As to the empirical support for the deterrence hypothesis, see S. Levitt and T. Miles, 'Empirical Study of Criminal Punishment' in Polinsky and Shavell, id., 455-96. See, also, F. Drago, R. Galbiati, and P. Vertova, 'The Deterrent Effects of Prison: Evidence from a Natural Experiment', CEPR Working Paper 6401 (2007). 
literature has pursued the optimal choice between private and public enforcement. However, the economic characterization of the choice as between relying on private prosecution (with particular reference to tort and contractual liability) or on public prosecution (usually assumed to be criminal liability, but in fact also including other forms of public enforcement such as administrative law) has not been completely satisfactory. Probably the most comprehensive and ambitious existing economic theory of 'why criminal law?' is proposed by Richard Posner. ${ }^{32} \mathrm{He}$ argues that the fundamental difference between torts and crime is that both punish behaviour that bypasses existing markets but that, whereas crimes are purely coercive transfers, torts are accidents of productive activities. He immediately acknowledges that there are several important counter-examples. Moreover, this distinction (coercive transfer or not) cannot explain why particular activities are criminalized and others not. We therefore prefer to rely on the role of the victims and the nature or magnitude of harm to determine the efficiency of using criminal law sanctions.

Once we understand the use of public enforcement, it is relevant to distinguish between criminal and administrative law (or any other forms of public enforcement that do not rely on criminal law). Economics has argued for criminalization when certain conditions are satisfied.

\section{Why public enforcement?}

The economics of enforcement is about the control of 'negative externalities' where one person's actions impinge negatively on one or more third parties. Discharging noxious smoke from a factory is a negative externality if the smoke adversely affects neighbours. If, however, the factory owner is made liable for compensating victims of the damage or faces administrative or criminal sanctions for discharging smoke, then the consequences become internalized to calculations about whether to build the factory or how much smoke to produce. A central concern in the law and economics literature is the structure of the compliance incentives created by the alternative instruments, whether used singly or in combination.

In fact, the economics of crime is quite loose in its use of the word 'crime', certainly not always following the precise legal meaning. In the economic perspective, crime will generally involve non-consensual harm, whether to someone else or to society as a whole. Theft from a person may affect just the individual victim. But criminal damage to public property, for example, may affect all residents in an area. In many instances there will be costs for both a second party (victim) and other third parties (individuals who

32 R. Posner, 'An Economic Theory of Criminal Law' (1985) 85 Columbia Law Rev. 1193-231. Further work by Richard Posner on crime includes T.J. Philipson and R.A. Posner, 'The Economic Epidemiology of Crime' (1996) $39 \mathrm{~J}$. of Law and Economics 405-33. 
are affected in some way but would not regard themselves as the principal direct victims). A physical attack or burglary committed against a person has substantial implications for the injured person but may also have an external impact on other citizens who respond by taking additional precautions.

Decisions about the choice of control device (including instruments which are sometimes loosely and incorrectly described as 'criminal law' by economists) will be based on assessment of a set of characteristics: the social value of compliance (that is, internalization of externality) by direct comparison of benefits to the offender and costs to the injured parties; enforcement technology (including the costs of damage monitoring and reporting and the costs of enforcing punishment); the relative costs to different groups (including the taxpayer, victims, and witnesses of activities) of employing or triggering the devices to control or minimize negative externalities (in particular, the impact of asymmetries of information on behaviour of different parties); and processes through which decisions are made about the choice of enforcement mechanism (the political economy of law enforcement). The extensive literature on optimal law enforcement recommends different sanctioning policies depending on the relative characteristics of the acts and the parties.

Whatever the optimal degree of internalization of a negative externality, there is debate about whether it is more efficiently achieved by private or public enforcement. There is a vast literature extending the seminal work of Coase in 1960 on how a privately-negotiated solution to negative externalities is better than the traditional Pigou taxation approach. ${ }^{33}$ In the realm of criminal and civil liability, we cannot simply say that private enforcement is a Coasian solution (because, for example, litigation takes place in state courts) while public enforcement is a Pigou approach (since, for example, in criminal law there may be plea-bargaining). Nevertheless, the debate over public versus private enforcement has been presented as an argument about whether there is justification for state intervention, that is, whether the determination of the sanction imposed for offences should be a concern for the state. ${ }^{34}$ Building on the Coasian approach to externalities, public enforcement is justified when there are high transaction costs between parties and hence a private solution is likely to fail.

We look at several reasons for these high transaction costs, namely, intent, imperfect detection by direct victims (collective action problem), low detection rate (enforcement technology), and judgment proof-ness or insolvency (need of enforcing imprisonment). We also consider the compensatory versus punitive nature of law enforcement.

33 See R. Coase, 'The Problem of Social Cost' (1960) 3 J. of Law and Economics 1-44, and G. Calabresi and A.D. Melamed, 'Property Rules, Liability Rules, and Inalienability: One View of the Cathedral' (1972) 85 Harvard Law Rev. 1089-128.

34 See R. Cooter, 'Prices and Sanctions' (1984) 84 Columbia Law Rev. 1523-60, on fines not being prices. 
A critical characteristic of criminal law as a control device from an economic perspective is that it enables a range of sanctions to be imposed on the transgressor that are not available using other instruments. ${ }^{35}$ Sanctions such as imprisonment impose high personal opportunity costs, and thus potentially represent a greater deterrent than monetary sanctions. Such sanctions are, however, often costly to impose and have little if any compensatory power from a victim's perspective. They can be imposed only after lengthy and costly hearings to protect the interests of innocent defendants. From a victim's perspective, the costs of using such an instrument might be disproportionate to the private returns, leaving it as something which is, or may be, worthwhile only from a collective perspective.

The aim is to provide an economic explanation for the boundary between private and public law enforcement. Richard Epstein, for example, sees the distinction between criminal and tort law as basically driven by ideological considerations concerning state intervention (expansion of liability is driven by government), first as developed in common law and then later by statute law. In his view, it is critical to recognize that many of today's law enforcement problems arise from the overall expansion of liability (both civil and criminal) to criminalize types of conduct that had been unquestionably legal before the passage of new law. Therefore, theories that concentrate on the role of mens rea in determining criminal liability (a point we develop later) or the reach of proximate causation in determining civil liability miss the central point, namely, which conducts should be punished. Hence, in his view, we should constrain the scope of both criminal and civil liability, possibly shrinking both domains simultaneously. Secondly, we should avoid overlapping them because of over-deterrence, a point we emphasize later. To support his theory, Epstein remarks that today the state spends more time on enforcing administrative regulations than criminal law, a point in our view related to the financial advantages of administrative penalties for the state. ${ }^{36}$

Nevertheless, economists have often pointed at the weaknesses of the private law in dealing with externalities. Shavell's criteria for safety regulation indicate that regulatory approaches are warranted when public authorities have better information on risk reduction, when potential injurers face insolvency or when there will be no deterrent effect from a liability suit (for example, because of problems of latency, causation or proof). ${ }^{37}$ These criteria are important since they indicate that in some cases regulatory

35 We note however that imprisonment has not always been a sanction preserved exclusively, or even principally, for matters today regarded as crimes. Charles Dickens's father, John, for example, spent time in a debtors' prison.

36 See R. Epstein, 'The Tort/Crime Distinction a Generation Later' (1996) 76 Boston University Law Rev. 1-21.

37 See S. Shavell, 'Liability for Harm versus Regulation of Safety' (1984) 13 J. of Legal Studies 357-74 and S. Shavell, 'A Model of the Optimal Use of Liability and Safety Regulation' (1984) 15 Rand J. of Economics 271-80. 
solutions may be more effective in controlling externalities than private law. They may point in the direction of criminal law, but not necessarily. Regulatory solutions can in some cases also be enforced through administrative sanctions.

We turn now to a detailed discussion of the elements that are relevant from an economic perspective.

\section{(a) Mens rea}

The notion of mens rea, is an essential element of a crime, as discussed in section II. 1 above. However, this does not necessarily mean that intent, in the sense that the actor must have wished the harmful consequences, is always a condition for applying the criminal law. Intent (deliberate causing of harm) is just one extreme on a continuum that has negligence (failure to take care) as its other extreme and includes recklessness (conscious disregard for risk) somewhere in between. The economic analysis of (potentially) harmgenerating activity implicitly assumes that actors are conscious of the scale of damage they are doing, or might be doing, whether the damage is a certain consequence of their action or is just a contingency with a known, or knowable, probability. There may be uncertainty as to the extent of harm that will be caused in a particular instance: critical is that the injurer is aware of the potential for causing harm.

Hence, intent is largely a way of characterizing the mental state of an injurer. Since this cannot be accurately or cheaply observed by enforcers after the event, it represents a comparatively weak basis for public enforcement in general, and an economic analysis of criminal law in particular. ${ }^{38} \mathrm{~A}$ further difficulty is that there are some perfectly lawful activities in which a person is behaving in a way that is known to be potentially harmful to second or third parties. Hence, we believe that the notion that crimes might be distinguished from other acts by virtue of the element of intent is in practice not a very useful criterion. Not only may negligent actions sometimes also be intentional (and nevertheless not fall under the scope of the criminal law, the so-called intentional torts) but also there are many regulatory offences that fall under the scope of the criminal law and yet do not require intent. ${ }^{39}$

Nevertheless economics can make sense of intent and public law enforcement if we take account of negative reciprocity that increases transaction costs. If harm is imposed deliberately, it is less likely that injurer

38 See T. Miceli, The Economic Approach to Law (2004) ch. 9. See, also, Posner, and Philipson and Posner, op. cit., n. 32, on providing an economic justification for the use of intent in criminal law. We depart from Posner's original argument by taking a sceptical tone concerning his economic explanation of intent. We take the view that the reciprocity argument is more promising.

39 In case of these regulatory offences, many legal systems often merely require that the perpetrator knowingly violated the law and that no grounds of excuse or justification are available. 
and injured are willing to engage in private negotiation. Accidental harm by contrast does not entail animosity towards the injured party, and therefore private enforcement is more likely to be efficient. ${ }^{40}$

(b) Imperfect detection by victims

A typical argument for public enforcement considers the incentives of victims after the event to mobilize enforcement devices that communicate efficient signals to potential harmers. There are a number of strands to this argument:

(i) victims may not have the right incentive to prosecute: they want compensation and do not care about general deterrence, also there might be a collective action problem if the expected return from prosecution is quite low ${ }^{41}$

(ii) victims may not have the right information: enforcers know better or victims do not even recognize that they are victims; ${ }^{42}$

(iii) victims may not have the right technology: they do not have economies of scale $^{43}$ or profit-orientation would not lead to efficient detection; ${ }^{44}$

(iv) victims might not be able to intervene ex ante to stop the harmful activity from taking place: regulatory intervention is more effective than private injunction;

(v) victims or witnesses of crimes might be deterred from engaging in private prosecution (or even reporting an action to the police) if they fear retaliation. ${ }^{45}$

Moreover, in many cases there may not be an easily identifiable victim at all (as with bribery or corruption). In some cases, an entire community may be victimized (environmental pollution) but no individual victim will have sufficient incentives to sue.

40 See W.M. Landes and R. Posner, 'An Economic Theory of Intentional Torts' (1981) 1 International Rev. of Law and Economics 127-54.

41 See S. Shavell, 'The Fundamental Divergence between the Private and Social Motive to Use the Legal System' (1997) 26 J. of Legal Studies 575-612. On optimal precaution by victims, see N. Garoupa, 'Optimal Law Enforcement when Victims are Rational Players' (2001) 2 Economics of Governance 231-42.

42 Shavell, op. cit., n. 30.

43 id.

44 See discussion by G. Becker and G.J. Stigler, 'Law Enforcement, Malfeasance, and Compensation of Enforcers' (1974) 3 J. of Legal Studies 1-18; W.M. Landes and R. Posner, 'The Private Enforcement of Law' (1975) 9 J. of Legal Studies 105-27; D.D. Friedman, 'Efficient Institutions for the Private Enforcement of Law' (1984) $13 \mathrm{~J}$. of Legal Studies 379-97; also A.M. Polinsky, 'Private versus Public Enforcement of Fines' (1980) $9 \mathrm{~J}$. of Legal Studies 105-27; N. Garoupa, 'A Note on Private Enforcement and Type I Error' (1997) 17 International Rev. of Law and Economics 423-9; and N. Garoupa and D. Klerman, 'Optimal Law Enforcement with a RentSeeking Government' (2002) $4 \mathrm{Am}$. Law and Economics Rev. 116-40.

45 Shavell, op. cit., n. 30. 
Another argument about public enforcement (in particular, criminal law) concerns the provision of focal points that help victims to take the right precautions and reduce asymmetry of information concerning preferences or harm. In many cases, individuals are not very sure about how to react to certain types of behaviour (for example, so-called 'anti-social behaviour'). The state provides the necessary device to coordinate actions. Hence public enforcement has an expressive role. ${ }^{46} \mathrm{~A}$ serious limitation of this theory is that the mechanism by which individuals understand and process the information provided by focal points is not as yet well understood.

Some scholars argue that public enforcement aims at expropriating from victims the compensation (or even rents) that could be extracted by private bargaining. Public enforcement may have the effect of generating money for the state at the expense of victims. There are different specifications of rentseeking theories of public enforcement, but mostly they show that the use of fines or property forfeiture might reveal some hidden objective in directly regulating negative externalities. ${ }^{47}$ However, the use of imprisonment (and other non-monetary sanctions), the existence of criminal injury compensation schemes, and also the availability of private actions alongside criminal prosecution reveal that the state is not just a Leviathan. If it were, we should observe a substitution of monetary for non-monetary sanctions to the fullest possible extent, a policy recommended by some ${ }^{48}$ but hardly consistent with the actual use of non-monetary sanctions: these are quite costly but still widely used.

In sum, imperfect detection by victims provides a serious argument for state intervention in order to achieve efficient control of negative externalities. We should nevertheless recognize that for some specific injuries (those with well-identified victims and for which asymmetries of information are not so likely), it is a puzzle why we should rely on public enforcement from this perspective.

\section{(c) Enforcement technology}

Another and probably very powerful reason that has been advanced in the economics literature in favour of the use of public enforcement is that in some cases there may be a relatively high degree of damage and a relatively

46 See, for example, R. McAdams, 'A Focal Point Theory of Expressive Law' (1996) 86 Virginia Law Rev. 1649-729 or D. Dharmapala and R. McAdams, 'Words that Kill? Economic Perspectives on Hate Speech and Hate Crime' (2005) 34 J. of Legal Studies 93-136.

47 D. Friedman, 'Why not Hang Them All: The Virtues of Inefficient Punishment' (1999) 107 J. of Political Economy 259-69; J. Lindgren, 'Why the Ancients May Not Have Needed a System of Criminal Law' (1996) 76 University of Boston Law Rev. 29-57, and M. D'Antoni and R. Galbiati, 'A Signaling Theory of Nonmonetary Sanctions' (2007) 27 International Rev. of Law and Economics 204-18.

48 A.M. Polinsky and S. Shavell, 'The Optimal Use of Fines and Imprisonment' (1984) $24 \mathrm{~J}$. of Public Economics 89-99. 
low chance of catching the offender. ${ }^{49}$ The economic theory of crime and punishment is grounded on the deterrence viewpoint, according to which threatening a potential criminal with serious punishment, such as imprisonment or high fines, will deter the intended crime. So why use public law? The argument is that a similar deterrent effect could not be achieved through the use of other legal instruments such as tort law.

The only risk that a potential criminal runs under a liability rule is that he will have to pay compensation equal to the amount of damage caused. With economic offences or environmental crime, for example, the probability of being caught for violation of a regulatory norm is often much lower than 100 per cent and so there will be significant under-deterrence, as was the case with imperfect detection by victims. Deterrence only works if the sanction is much higher than the amount of damage being caused. Thus, a probability of detection substantially less than 100 per cent is a powerful argument in favour of using public law to deter offences. ${ }^{50}$

In some areas of crime, such as prostitution or drug dealing, there is no obvious 'victim' wanting to file a complaint. In addition the offence may be repeated frequently while a prosecution can normally only be brought in relation to specific instances for which evidence is produced. As we have shown in recent papers on the treatment of illegal gain, the enforcement response may be to use a combination of both criminal and civil procedures allowing for the confiscation of the gains from illegal activity without the prosecution having to demonstrate the link between accumulated wealth and individual crimes or deals. ${ }^{51}$ Moreover, the existence of 'victimless crime' (where externalities are generated that affect society at large but no individual victim has an incentive to sue) is more generally an argument in favour of public enforcement.

\section{(d) Compensation versus the punitive nature of enforcement}

A typical argument for public intervention for controlling externalities is that the internalization of harm via civil law is imperfect. Civil law, particularly tort law, never guarantees the victim full compensation. This would require that the victim be indifferent ex ante as to whether he is (i) injured and compensated or (ii) not injured. ${ }^{52}$ This is only possible if civil law can

49 Shavell, op. cit., n. 30.

50 This point has also been made by G. Skogh, 'A Note on Gary Beckers' Crime and Punishment: An Economic Approach' (1973) Swedish J. of Economics 305-11, and G. Skogh and C. Stuart 'An Economic Analysis of Crime Rates, Punishment and the Social Consequences of Crime' (1982) Public Choice 171-9.

51 See R. Bowles, M. Faure, and N. Garoupa, 'Economic Analysis of the Removal of Illegal Gains' (2000) 20 International Rev. of Law and Economics 537-49; R. Bowles, M. Faure, and N. Garoupa, 'Forfeiture of Illegal Gain: An Economic Perspective' (2005) 25 Oxford J. of Legal Studies 275-95.

52 In unilateral acts, if the victim is also able to reduce the probability of harm, then some under-compensation might be optimal to solve the moral hazard problem. There 
completely compensate the victim for the harm caused. However, even if the victim receives substantial financial compensation, this will never put him in the position he was in before the accident occurred. Hence, the amount that will be awarded under civil law is often too low to guarantee effective deterrence from an economic point of view. ${ }^{53}$ Some have argued that the goal of criminal law in these types of cases is not to compensate, but primarily to deter. Robert Cooter has articulated this viewpoint by claiming that, in civil law, individuals in principle have the right to cause damage to someone else, on the condition that they are willing to pay the price for that damage, that is, to compensate the victim. Criminal law, however, aims to prohibit certain anti-social behaviour even if the offender were willing to pay the price in the form of compensation to the victim. Therefore, Cooter has argued, whereas civil law fixes a price for behaviour in the form of a sanction, criminal law simply wishes to deter by imposing sanctions. ${ }^{54}$

Whether the main problem with tort law is the limit on compensation to the victim or a low detection rate, the solution is to increase compensation payable by the injurer under tort law. That is precisely the idea behind the concept of 'punitive damages' as an alternative to criminalization. ${ }^{55}$ Such legal policy is quite controversial because it introduces characteristics of criminal punishment into civil procedures: in particular, it dilutes the distinction between punishment in criminal law and compensation in civil law. ${ }^{56}$ Also, it seems clear that 'punitive damages' are applied in many situations where the probability of detection and punishment is quite high, thus possibly creating over-deterrence. ${ }^{57}$

For many legal scholars the distinction between civil and criminal law is precisely based on whether the principal consequence of a conviction is compensation of the victim or punishment of the offender. ${ }^{58}$ Therefore the

is nevertheless a trade-off since under-compensation of victims also reduces injurers' incentives.

53 See M. Faure, 'Compensation of Non-Pecuniary Loss: An Economic Perspective' in European Tort Law, Liber Amicorum for Helmut Koziol, eds. U. Magnus and J. Spier (2000) 143-59.

54 Cooter, op. cit., n. 34

55 R.D. Cooter, 'Economic Analysis of Punitive Damages' (1982) Southern California Law Rev. 97-101, and see F. Easterbrook, 'Criminal Procedure as a Market System' (1983) $12 J$. of Legal Studies 289-332. See, further, on the economic analysis of criminal procedure, C.Y. Chu, 'Note: An Economic Analysis of the Criminal Proceedings in Civil Law Countries' (1991) 11 International Rev. of Law and Economics 111-16, and T. Miceli, 'Optimal Criminal Procedure: Fairness and Deterrence' (1991) 11 International Rev. of Law and Economics 3-10.

56 See P. Robinson, 'The Criminal-Civil Distinction and the Utility of Desert' (1996) 76 Boston University Law Rev. 201-14.

57 See A.M. Polinsky and S. Shavell, 'Punitive Damages: An Economic Analysis' (1998) 111 Harvard Law Rev. 869-962.

58 D.J. Seipp, 'The Distinction between Crime and Tort in the Early Common Law' (1996) 76 Boston University Law Rev. 59-87. 
boundary between private and public law should be determined by the nature of the conviction, compensatory versus punitive. David Friedman ${ }^{59}$ presents a powerful critique. Although it is tempting to frame the distinction between tort and crime as a problem of combining private versus public prosecution in conjunction with punishment versus compensation, prevention versus pricing, and moral stigma, Friedman shows that there are many examples that undermine a clear correlation between all these characteristics. We therefore argue that the nature of compensatory versus punitive actions is not the best way of thinking about the boundary between private and public law.

\section{Why criminal law?}

Public enforcement of the law might be appropriate where criminalization is one form of public enforcement. Criminal law and criminal sanctions are just one mechanism for dealing with externalities. Other legal institutions are potential competitors whilst there is generally the option of taking no action and relying on non-legal devices such as social or religious norms or some form of private negotiation to fill the void. In distinguishing between criteria for regulation and criteria for criminalization, there is unavoidably some overlap.

As far as the difference between civil liability and regulation is concerned, there is the economic literature on safety regulation, discussed in the introduction to this section. ${ }^{60}$ However, this literature only points in the direction of regulation: it does not necessarily lead to the conclusion that this ex ante regulation should necessarily be enforced through the criminal law.

So far we have advanced arguments to show that, in some cases, civil law cannot provide an adequate deterrent to socially harmful behaviour. Apart from the use of imprisonment, we have not provided any major argument for criminal law over administrative law. We have argued that, especially when there is imperfect detection by victims and when the probability of detection is low, public enforcement should be used since only this system will allow the imposition of high, deterrent sanctions. The question, however, still arises why these sanctions should necessarily take the form of the criminal law, where the sanction can include imprisonment. If the sanctions to be imposed were limited to (modest) fines, in theory, these could also be imposed via administrative law. We argue, however, that there are economic reasons for not having high sanctions (high fines or imprisonment) imposed by administrative authorities even though the procedure for imposition may be cheaper.

59 D. Friedman, 'Beyond the Tort/Crime Distinction' (1996) 76 Boston University Law Rev. 103-12.

60 In addition to the well-known work of Shavell (op. cit., n. 37) in this respect we can also point, among others, to D. Wittman, 'Prior Regulation versus Post Liability: The Choice between Input and Output Monitoring' (1977) 6 J. of Legal Studies 193-211. 
Our reasoning for a boundary between administrative and criminal law is efficiency-driven. We therefore depart from the distinction between administrative and criminal law being based on a distinction between blueand white-collar crime, although Posner argues it makes sense based on the insolvency argument. ${ }^{61}$

\section{(a) Imprisonment and other non-monetary sanctions}

A standard justification for relying on public enforcement is that imprisonment and other non-monetary sanctions (including capital punishment) are involved. In order to explain the use of non-monetary sanctions and, more particularly, their added value compared with administrative sanctions or fines, we need to consider the problem of insolvency. The literature has indicated that monetary sanctions can only be used up to the point where the actor becomes insolvent. ${ }^{62}$ Imprisonment should be used when fines are unable to achieve efficient deterrence. ${ }^{63}$ Such policy should be pursued when the probability of detection is quite low and the likelihood of the defendant being judgment-proof is quite high.

Since raising the probability of detection is costly, the insolvency risk may lead to the need to apply non-monetary sanctions. But why should these not be administrative or even private? Monetary sanctions can in principle be both criminal and administrative in nature. Compensatory and punitive damages are always monetary. Imprisonment cannot be imposed in tort litigation. An administrative agency cannot impose non-monetary sanctions such as imprisonment. Consequently, imprisonment is almost always only available as a criminal sanction, not as an administrative sanction. Thus when acts cannot be deterred by monetary sanctions alone, some form of public enforcement system is required, and criminal law in particular. ${ }^{64}$

There is yet another economic argument for not wanting very stringent sanctions, such as imprisonment, to be imposed in administrative proceedings. The reason, as Frank Easterbrook has pointed out, is that the goal of criminal and administrative proceedings is simply to uncover all the appropriate information about the facts at the lowest cost possible, and to provide the necessary information for the judge to apply the optimal sanctions. ${ }^{65}$ Obviously the cost of administrative proceedings may be lower than that of criminal proceedings, but the accuracy of the latter (where the

61 Posner, op. cit., n. 32.

62 S. Shavell, 'Criminal Law and the Optimal Use of Non-monetary Sanctions as a Deterrent' (1985) 85 Columbia Law Rev. 1232-62.

63 Polinsky and Shavell, op. cit., n. 48.

64 For an application in environmental law, see M. Faure, I. Koopmans, and J. Oudijk, 'Imposing Criminal Liability on Government Officials under Environmental Law: A Legal and Economic Analysis' (1996) 18 Loyola of Los Angeles International and Comparative Law J. 529-69.

65 Easterbrook, op. cit., n. 55; Chu, op. cit., n. 55; Miceli, op. cit., n. 55. 
investigations are often undertaken by professional lawyers) may be a lot higher. This is important because the task of criminal law is not only to apply optimal sanctions to the guilty, but also to avoid punishing the innocent and thereby to reduce error costs. ${ }^{66}$ The error cost is obviously a lot higher when very serious non-monetary sanctions, like imprisonment, may be imposed. Thus less costly administrative proceedings are chosen in cases where the consequences (and thus the error cost) will not be too high in the event of wrongful conviction. ${ }^{67}$

Therefore, the reason why imprisonment should be applied only by public law, in particular criminal law, has to do with court errors or miscarriages of justice. The disutility (private and social) of imprisonment is much higher than a monetary fine, hence the cost of wrongful convictions is socially more significant. It requires a higher standard of proof to avoid costly mistakes and criminal law provides the most appropriate setup. ${ }^{68}$ Incapacitation is a second line of reasoning to justify the use of imprisonment and thus public law enforcement. When the main goal is incapacitation and not deterrence, fines and monetary sanctions are quite ineffective, and hence we need criminal law. ${ }^{69}$

\section{(b) Stigma}

Criminal law may be able to create more stigma than other kinds of sanctions and thereby act as a more effective deterrent. ${ }^{70}$ However, the economic literature on 'shaming' indicates that stigma effects vary across individuals.

66 On the costs of punishing the innocent, see, also, T. Miceli, 'Optimal Prosecution of Defendants whose Guilt is Uncertain' (1990) $6 \mathrm{~J}$. of Law, Economics and Organization 189-201.

67 This argument explaining administrative penal law has been advanced by A. Ogus and C. Abott, 'Pollution and Penalties' in An Introduction to the Law and Economics of Environmental Policy: Issues in Institutional Design, ed. T. Swanson (2002) 493518.

68 See N. Garoupa and F. Gomez, 'Punish Once or Punish Twice: A Theory of the Use of Criminal Sanctions in Addition to Regulatory Penalties' (2004) 6 American Law and Economics Rev. 410-33, for discussion. For a more historical perspective, see Lindgren, op. cit., n. 47, pp. 29-57.

69 See S. Shavell, 'A Model of Optimal Incapacitation' (1987) 77 Am. Economic Rev. 107-10.

70 Rasmusen develops the idea of using stigma as a deterrent, although Funk presents important objections to it. See E. Rasmusen, 'Stigma and Self-Fulfilling Expectations of Criminality' (1996) $39 \mathrm{~J}$. of Law and Economics 519-44, and P. Funk, 'On the Effective Use of Stigma as a Crime-Deterrent' (2004) 48 European Economic Rev. 715-25. See, also, A. Klement and A. Harel, 'The Economics of Stigma: Why More Detection of Crime May Result in Less Stigmatization' (2007) 36 J. of Legal Studies 355-78; R. Galbiati and N. Garoupa, 'Keeping Stigma Out of Administrative Law: An Explanation of Consistent Beliefs' (2007) 15 Supreme Court Economic Rev. 273-83. 
Stigma may not deter career criminals: they may even regard it as a 'badge of honour'. ${ }^{71}$

\section{(c) Enforcement specialization and capture}

Administrative authorities often seek to achieve voluntary compliance by an offender through a strategy of cooperation. This can be effective because it makes use of expertise and regulatory specialization, but it has disadvantages as well. It may not provide ex ante enough incentives to potential polluters to follow legal requirements. Moreover, problems often arise when attempts at voluntary compliance finally fail following a period during which administrative agencies have been cooperating with offenders. Administrative authorities often then find themselves with 'their hands tied' and unable to act effectively as enforcers against offenders with whom they initially cooperated.

One should, however, be careful about making a generalized judgement to the effect that administrative proceedings would be inefficient because of the risk of collusion between industry and agencies. Proponents of public choice theory have argued that, especially where poorly-informed administrative officials try to control powerful and well-informed enterprises, there is a serious 'capture risk', that is, a danger that some form of collusion will occur, that compliance will not follow, and deterrence will fail. However, it is too simple to reject administrative proceedings and the resulting cooperative strategies altogether based on this capture risk. ${ }^{72}$

A related matter is the separation between investigation and prosecution in criminal procedure but not in administrative enforcement. The issue of separation versus integration balances the specialization gains (including a reduction in errors in evaluating evidence) against the coordination costs (including capture and agency costs). Regulatory agencies are typically industry-specific and tax authorities are quite specialized. Hence, there is no substantial specialization gain in further separation but there could be important costs, in particular significant agency costs. For the criminal justice system, the specialization is quite justified, because criminal law is more powerful and any mistake is more harmful. ${ }^{73}$

71 See Note on 'Shame, Stigma and Crime: Evaluating the Efficacy of Shaming Sanctions in Criminal Law' (2003) 116 Harvard Law Rev. 2186-207.

72 See discussion by P. Fenn and C. Veljanovski, 'A Positive Economic Theory of Regulatory Enforcement' (1988) 98 Economic J. 1055-77.

73 We acknowledge that it is a matter of debate if the administrative procedure is less accurate, but it is certainly less rule-governed. 


\section{(d) Coexistence of systems}

We have explained why, from an economic perspective, some activities can only be deterred by using the criminal law. However, the arguments in favour of criminal law do not imply that criminal law is the only instrument for controlling an externality. The basic problem remains that applying the criminal law is very costly relative to alternatives such as private law and administrative law and so, in practice, a combination of enforcement strategies is often employed. For example, administrative enforcement may be used up to the point where the insolvency of the perpetrator makes it necessary to apply criminal sanctions. In practice, of course, this kind of income-based or wealth-based discrimination will rarely be tolerated. But there certainly are instances where the alternatives are used in tandem. The downside of employing multiple methods is duplication of costs and potential over-deterrence.

Another argument for coexistence is combination of flexibility (of administrative law) and complexity (of criminal law). Since criminal punishment is more costly (with a higher standard of proof) and mistakes are more costly, criminal law should be more transparent and clearer. The downside is that a more comprehensive legal body offers less flexibility and increases complexity. ${ }^{74}$ In a dynamic world, we might require a more flexible law (with a lower standard of proof) for certain economic and social activities. But this flexibility requires more specialized interpretation and timely enforcement, and thus administrative rather than criminal law. Administrative law is intrinsically more incomplete than criminal law, and regulatory and administrative agencies have a much more influential role than the police or the prosecutors in shaping the law. Co-existence facilitates a combination of flexibility in some areas and complexity in other areas.

In practice it requires a lot of balancing to discern whether a combination of sanctions is a better solution than using a single instrument. Take the case of an airline company guilty of price fixing. Large externalities may be at stake, but individual victims (every individual paying too much for the ticket) may lack incentives to sue. Since private enforcement will not provide sufficient deterrence, public enforcement is indicated. This should, however, not necessarily take the form of the (costly) criminal law. Even though it may be difficult to discover the price fixing between airline companies, detection costs for monitoring authorities should not be too excessive. If the probability of detection is still reasonable, a monetary sanction (fine) can suffice. Moreover, even if the probability of detection were (given lower enforcement possibilities) substantially lower and thus the fine should be substantially increased (to outweigh this low detection rate),

74 K. Pistor and C. Xu, 'Incomplete Law - A Conceptual and Analytical Framework and its Application to the Evolution of Financial Market Regulation' (2003) $35 \mathrm{~J}$. of International Law and Politics 931-1013. 
criminal law is not immediately necessary either. This may depend on the solvency of the airline(s) involved. If their financial assets are substantial so that they could even pay the higher fine, it could still take the form of an administrative penalty. However, the question then arises if the procedure according to which such a high penalty is imposed can guarantee that error costs are reduced. If that were not the case, the criminal law may be indicated because of its higher procedural accuracy. The same conclusion would also be reached if the efficient sanction would be so high as to exceed the limits of the airline involved. ${ }^{75}$ For those reasons the criminal law may be needed to impose non-monetary sanctions (for example, a prohibition on flying during a certain period) upon the airline. A final issue would be whether the administrative fine would inflict sufficient negative stigma upon the airline involved. Even though administrative sanctions may involve some 'naming and shaming, ${ }^{76}$ the stigma inflicted through criminal law may be more substantial. If, given the specific characteristics of the case, using the criminal law may inflict a reputational loss upon the airline, this could also be an element to involve the criminal law.

\section{A model of criminal law}

What seems evident is that there are certain characteristics of activities making them more likely to be the subject of criminal sanctions. We have relied largely on economic reasoning to identify criteria for choosing between regulation and a public sanctioning system on the one hand and use of the criminal law on the other. Our findings thus far can be summarized as follows.

Essentially the boundary between private and public law has to do with the role of the victims, not in the narrow sense of compensatory versus punitive intervention, but in a complex setting of appropriate incentives. In cases where (as a result of bounded rationality, significant asymmetries of information, irresponsibility, and problems of causation, latency or proof) the deterrent effect of a tort law may fail, regulation and enforcement through the public law becomes necessary. When there is imperfect detection by victims (where damage is diffuse in character), again private law remedies may not suffice and an intervention of a regulation with public law sanctions will be necessary. When an ex ante prohibition of certain behaviour seems more desirable than allowing the perpetrator to commit the harm and pay the corresponding price, a prohibition enforced with public

75 In this particular case one would have to take into account first of all the limited liability of the airline which is undoubtedly organized as a corporation, and second, the fact that administrative authorities may not be willing to impose ultra-high fines (even if the statute involved would already allow them to do so).

76 A downside of shaming sanctions via administrative law is that error costs may be substantial. See Galbiati and Garoupa, op. cit., n. 70. 
sanctions is more appropriate. Where the probability of detection is low, the corresponding sanction should be higher than the damage to society (or the benefit to the perpetrator) in order to outweigh the low detection rate. ${ }^{77}$ However, in many cases, the probability of detection is, certainly ex post (at the sanctioning stage), hard to influence. Since a low probability of detection is therefore often a given, the question in practice only arises ex post, namely, how to set an efficient sanction given this low detection rate.

Apart from the use of non-monetary sanctions (due to insolvency or incapacitation), the boundary between criminal and administrative law should be determined by the role of stigma, the need for specialization in enforcement, or further combination of flexibility and complexity of the law.

This summary can be expressed in a typology of harm protection, as in Table 1. For example, the insolvency problem mentioned above will probably be larger more particularly in the case of large-scale damage or when there is a single harm producer (for whom the amount of harm will easily exceed individual wealth). This causes well-known problems due to the limitation of liability of corporate entities, for example. Based on this schedule one can also

Table 1. Typology of harm production

Damage diffusion $\rightarrow$

\begin{tabular}{|c|c|c|c|}
\hline \multirow{3}{*}{$\begin{array}{c}\text { Scale of } \\
\text { damage } \\
\downarrow\end{array}$} & & Concentrated loss & Diffuse loss \\
\hline & Small & PRIVATE LAW & $\begin{array}{l}\text { CRIMINAL/PUBLIC LAW } \\
\text { ('Victimless' crime, for } \\
\text { example, prostitution) } \\
\text { ADMINISTRATIVE/ } \\
\text { PUBLIC LAW } \\
\text { (Tax evasion) }\end{array}$ \\
\hline & Large & $\begin{array}{l}\text { CRIMINAL/ } \\
\text { PUBLIC LAW } \\
\text { (Murder, rape) }\end{array}$ & $\begin{array}{c}\text { CRIMINAL/ } \\
\text { PUBLIC LAW } \\
\text { (Major environmental } \\
\text { offences) }\end{array}$ \\
\hline
\end{tabular}

77 The literature on the trade-off between the detection rate and penalties indicates that, given risk aversion, limits on punishment, and the insolvency risk, raising the probability of detection may in some cases be more efficient than raising the sanction; see, empirically, I. Ehrlich, 'Participation in a Legitimate Activity: A Theoretical and Empirical Investigation' (1973) 81 J. of Political Economy 521-52. However, when talking about the limits on punishment, we should not ignore that economics does not constitute the only rationale: see H.L.A. Hart, 'Prolegomenon to the Principles of Punishment' in his Punishment and Responsibility: Essays in the Philosophy of Law (1978) 1-27. 
argue that there may be higher transactions costs involved in achieving an efficient harm reduction level if losses are diffuse across society and losses are expected to continue unless the law is strictly enforced.

Based on the previously mentioned criteria and this typology of harm production, one can thus predict that criminal law will probably be more used (and also has a comparative advantage with respect to other systems) where: (a) the losses are diffuse; (b) the losses are relatively large (and hence insolvency is likely to be a problem).

For acts such as homicide, major wounding, rape, and theft, these two characteristics may combine. Major incidents can terrify whole neighbourhoods and induce widespread, very costly risk reduction measures on the part of large numbers of citizens. In the case of drug dealing and prostitution, the direct losses may be smaller but there may be the prospect of property values over wide areas falling significantly as house-buyers switch to less affected areas.

These are, as we mentioned above, precisely the cases where the deterrent effect of private law will probably fail because the incentives for victims are not aligned with the whole of society (the civil law can not constitute an alternative) and where the insolvency risk will be large (and thus administrative sanctions can not constitute an alternative).

We also propose that the historical evolution of criminal liability might be justified by changes in the nature or economic cost of victimization rather than the usual argument based on enforcement technology. As societies become more urbanized, with more mobility and valuable exchange of goods and services, on the one hand, and as economic activities become more specialized and complex on the other, it becomes more costly to society to have individuals engaging in activities to avoid potential victimization. Hence imperfect detection by victims becomes more likely, thereby strengthening the case for state intervention. ${ }^{78}$

\section{IMPLICATIONS}

According to the economic approach, the design of legal instruments and the rules about their use will be sensitive to social and economic conditions. The response to change may involve adjusting the degree of reliance on criminal law or criminal sanctions. An important implication is that any reform decisions formulated without reference to the underlying economics of the relevant markets may fail to align legal institutions with harm prevention objectives.

78 For other views, see D.D. Friedman, 'The Private Creation and Enforcement of Law: A Historical Case' (1979) 8 J. of Legal Studies 399-415; D.D. Friedman, 'Making Sense of English Law Enforcement in the Eighteenth Century' (1995) University of Chicago Law School Roundtable 2; F. Parisi, 'The Genesis of Liability in Ancient Law' (2001) 3 Am. Law and Economics Rev. 50-81. 
There are many areas in which the scope or operation of criminal sanctions is changing or is under review at present. We use the context of corporate law to consider briefly how the economic arguments developed in the previous section of the paper can be deployed in helping explain developments in corporate law. The key questions include why criminal sanctions are used, whether they are being used in isolation, and whether the scale and diffusion of damage can justify a tendency for greater use of criminalization.

\section{Sanctions in corporate law}

Financial scandals have prompted legislators and law reform agencies to give renewed consideration to the role of criminalization and criminal sanctions in corporate law. The large scale of the losses suffered by a wide cross-section of the population (including shareholders, current and former employees, and other stakeholder groups) and the nature of some of the misconduct by corporate executives have been sufficient to induce calls for greater use of criminal sanctions against miscreants. The diffuseness of the losses weakens the effectiveness of private monitoring and enforcement and strengthens arguments in favour of public enforcement either through regulation or criminalization.

Only rarely is there any suggestion that the harmful behaviour in question is the product of an intention to cause harm. Like social security fraud, for example, the behaviour is generally motivated by greed and a disregard of the consequences for other people, whether the victims be shareholders, creditors, beneficiaries of a company pension scheme, taxpayers or whoever. The low probability of detection reduces the deterrent power of civil sanctions and increases the attraction of criminalization.

But other commentators, concerned about the functioning of financial markets and the likely impact of greater criminalization, have argued that criminalization would have some negative consequences. Critics of the Sarbanes-Oxley law, drafted to tighten controls in the United States of America on accounting and other financial management in order to secure better corporate governance and protect individual investors, have argued, for example, that some of its provisions are costly to implement and unproductive. $^{79}$

Greater reliance on criminalization, it is argued, might make executives become unwilling to take (socially-justified) risky decisions and incline them to behave defensively. In addition, the higher standards of evidence required for criminal convictions could substantially raise enforcement costs and make it more difficult to bring sanctions to bear. This would apply particularly if a mens rea requirement were included.

79 See <http://www.inc.com/news/articles/200501/sarbox.html>. 
An explicit effort to configure the boundaries of criminal sanctions within corporate law so as to balance the conflicting demands of 'better business regulation' and efficient protection of stakeholders can be found in the review of sanctions in corporate law currently being conducted by the Australian Treasury. In reviewing the range of criminal, civil penalty, and civil sanctions currently used in Australian corporate law, ${ }^{80}$ the Report refers to the economics-based argument of Easterbrook and Fischel that the objective is to choose sanctions and substantive doctrines that 'minimise the sum of the losses from (a) undesirable behaviour that the rules permit, (b) desirable behaviour that the laws deter, and (c) the costs of enforcement'. ${ }^{81}$

The implication of this 'law and economics' approach is that the decision about criminalization is an empirical matter of how best to achieve efficiency objectives. Policy choices will reflect a balancing of business compliance cost considerations, arguments about moral standards and the role of stigma, the scale and diffusion of harm, the prospects for success in actions, and other aspects of enforcement costs. This is equivalent to arguing that policy makers will identify the various sources of social costs associated with the alternative legal instruments (or combinations of instruments) and choose a solution that minimizes the sum of theses costs.

\section{Criminalization in other areas of law}

Broadly similar sorts of arguments apply in a number of areas of law. In recent years in the United Kingdom, increasing numbers of medical practitioners have been charged with gross negligence manslaughter in circumstances where their errors have resulted in patient deaths. A change seemed to occur around 1990 in the interpretation by courts of what kinds of mistake were to be regarded as constituting 'gross negligence' warranting criminal prosecution as distinct from 'negligence' sufficient to trigger civil compensation. ${ }^{82}$ This gave rise to a shift in the choices made by victims and state prosecutors as to the circumstances respectively in which they would litigate and prosecute.

The requirement for indemnity insurance had possibly weakened the incentive for practitioners to exercise care and internalize external costs. Pursuing criminal sanctions in cases where the degree of malpractice exceeds significantly the level triggering a negligence claim provides a second, quite direct deterrent to lapses in practitioner performance. In practice, however, few prosecutions have succeeded. The high evidentiary

80 Treasury of the Commonwealth of Australia, 'Review of Sanctions in Corporate Law' (2007) 10.

81 F.H Easterbrook and D.R. Fischel, The Economic Structure of Corporate Law (1996) 316.

82 J. Holbrook, 'Criminalization of Fatal Medical Mistakes' (2003) 327 Brit. Medical J. 1118-19. See, also, O. Quick, 'Prosecuting "Gross" Medical Negligence: Manslaughter, Discretion, and the Crown Prosecution Service' (2006) 33 J. of Law and Society 421-50. 
standards required and the difficulty in establishing that the behaviour complained of really was of a different order of culpability from that required to establish negligence in a civil action combined to leave prosecutors reluctant to bring charges and criminal courts reluctant to find defendants guilty.

A somewhat similar motivation may be discerned in the growing use of criminal proceedings against seafarers in the context of maritime accidents with potentially catastrophic effects on the environment. The purpose of introducing criminal sanctions against seafarers is to remedy the weakness of incentives to bring private actions in the event of collisions or groundings. This weakness might result from various factors including: diffuseness of damage; seafarers being judgment-proof; and the high costs of pursuing ship-owners based overseas.

Some degree of environmental harm is accepted as a consequence of industrial activities. The application of criminal law in the environmental area tends to be reserved for instances where behaviour exceeds socially acceptable boundaries. ${ }^{83}$ This is consistent with our approach, but does not make explicit the grounds on where such boundaries are to be drawn. An economic approach, by contrast, can help formulate such requirements. For example, agents could be held criminally liable if they cause damage in circumstances where the expected social losses are disproportionate to the incident prevention costs. On the other hand, for many violations of environmental regulations, the use of the costly criminal law is not necessary. Minor violations of, for example, a duty to report the substances processed in a factory to administrative authorities could well be sanctioned using administrative law. Social harm is relatively limited, probability of detection may not be that low whereas the gain to the offender from this administrative omission may not be enormous. In those cases an administrative fine could suffice to deter. ${ }^{84}$

Many jurisdictions have passed laws that make the seriousness of some offences of violence sensitive to context, for example, violence in the home and hate crimes. ${ }^{85}$ An economic approach would justify this decision by looking at the costs imposed by violence on potential victims in the form of self-help or victimization avoidance, given a disproportional incidence of these kinds of crimes against women and minorities. ${ }^{86}$ These social costs are

83 S. Bell and D. McGillivray, Environmental Law (2005, 6th edn.).

84 See A. Ogus and C. Abott, 'Sanctions for Pollution: Do we have the Right Regime?' (2002) $14 \mathrm{~J}$. of Environmental Law 283-300; they also argue that the United Kingdom should make more use of administrative law in sanctioning violations of environmental laws in Ogus and Abott, op. cit., n. 67.

85 For example, the Crime and Disorder Act 1998 and the Domestic Violence, Crime and Victims Act 2004.

86 For hate crimes, see the debate in D. Dharmapala and N. Garoupa, 'Penalty Enhancements for Hate Crimes: An Economic Analysis' (2004) $6 \mathrm{Am}$. Law and Economics Rev. 185-207, and D. Dharmapala, N. Garoupa, and R. McAdams, 'The Just World Bias and Hate Crime Statutes', mimeograph (2007). 
increasing over time because of more active participation by women and minorities in the labour market. From an economic perspective we can argue that deterrence of these crimes is growing in importance, not because the scale of physical or psychic harm in individual cases has increased, but because the losses have become more transparent and spread further through their impact on business.

\section{CONCLUDING REMARKS}

The main purpose of this paper has been to demonstrate that an economic approach to criminal law can contribute significantly to the debate about the appropriate scope of criminalization and about the choice of legal form.

The Criminal Justice System (CJS) is costly to operate, but in exchange offers a means of controlling harmful activities that, if unchecked, would result in very high costs for victims and the wider community. Decisions about extending the scope of the criminal law have to balance the additional costs of running the CJS with the benefits society derives from the savings resulting from the reduced prevalence of harmful activity. The decisions also have to take account of the alternative means of control available. If private or administrative law solutions can provide the requisite degree of control, and can do so at lower cost, then there is likely to be a presumption that they represent a better approach than criminalization.

An economic perspective on criminalization focuses attention on the scale of costs activities impose on third parties. Where these costs are high, and exceed the benefits to the first party, the activity may be judged 'socially harmful'. Having established a prima facie case for control, the economic approach entails weighing the competing claims of a variety of legal and other instruments for controlling such socially harmful activities ranging from exhortation and social norms to civil, administrative, and criminal law. The final choice of instrument, or combination of instruments, for purposes of harm control then depends on a number of characteristics of the setting, including the structure of transactions and agency costs, and also on technology and individual tastes and preferences.

This approach has a number of implications for where and how criminal law is used. It is likely to be particularly effective relative to private law in the control of harm in settings where harm is diffuse, the probability of detection low, or defendants likely to be judgment-proof. The decision about whether an activity should constitute a criminal offence will thus be based on a comparison between alternative methods of controlling the activity and is not, in general, intrinsic to the activity. Changes in costs, technology, information sets, and tastes may prompt reconsideration of how best to control an activity thereby altering the definition of criminal activity or altering the balance between the types of legal instrument used to control it.

The economic model gives greater weight to the costs of an activity to 
third parties and less weight to the motivation for, or nature of, the activity itself in judging whether a class of actions should be criminalized. The approach is demanding from an empirical perspective, since it may require detailed inspection of how markets and incentives are operating and the scale and structure of costs being faced or experienced by third parties, whether as individual victims or broader groups.

The economic model is not, of course, alone in offering a framework for the analysis of law and legal reform. It has been used much more widely, thus far, in the analysis of private law. But we argue that it offers wider scope for application to criminal law than has been commonly appreciated. 